\title{
Pemindahan Ibu Kota Baru Negara Kesatuan Republik Indonesia ke Kalimantan Timur: Strategi Pemenuhan Kebutuhan dan Konsumsi Energi
}

\author{
Hanan Nugroho ${ }^{1}$ \\ Kementerian PPN/Badan Perencanaan Pembangunan Nasional - Indonesia
}

\begin{abstract}
Abstraksi
Penetapan Kalimantan Timur sebagai Ibu Kota Negara (IKN) baru berdampak perlipatan kebutuhan energi. Diusulkan prinsip dasar pemenuhan kebutuhan energi serta konsumsi energi: (i) Menjadikan pembangunan IKN momentum mengembangkan sistem penyediaan energi Kalimantan secara luas, (ii) Mengandalkan pemenuhan kebutuhan energi dari sumber-sumber lokal, (iii) Mengutamakan sumber-sumber energi Kalimantan untuk Kalimantan terlebih dahulu, (iv) Mengutamakan penggunaan energi bersih dan terbarukan, (v) Mengembangkan/ memperkokoh interkoneksi infratruktur energi se-Kalimantan, serta (vi) Menggunakan energi secara efisien. Diusulkan proyek strategis energi: (i) Pembangunan jaringan transmisi gas bumi dari lokasi ketersediaan gas bumi (atau LNG) di Kalimantan Timur ke IKN, (ii) Penguatan jaringan transmisi interkoneksi kelistrikan seKalimantan, (iii) Pembangunan PLTA skala besar memanfaatkan potensi sungai-sungai besar di Kalimantan, (iv) Pembangunan installasi dan penggunaan energi bersih, dan (v) Pembangunan sistem transportasi hemat energi dan ramah lingkungan.
\end{abstract}

Kata Kunci: ibukota baru, pemenuhan kebutuhan energi, konsumsi energi, gas bumi, energi terbarukan

\footnotetext{
${ }^{1}$ Hanan Nugroho adalah Perencana Ahli Utama (Energi \& Sumber Daya Mineral), Kementerian Perencanaan Pembangunan Nasional/Badan Perencanaan Pembangunan Nasional. Email: nugrohohn@bappenas.go.id
} 


\section{Pemindahan Ibu Kota Baru Negara Kesatuan Republik Indonesia ke Kalimantan Timur: Strategi Pemenuhan Kebutuhan dan Konsumsi Energi}

Hanan Nugroho

\section{Pendahuluan}

Wilayah di Kalimantan Timur telah ditetapkan menjadi Ibu Kota Negara (IKN) baru Negara Kesatuan Repulik Indonesia. ${ }^{2}$ Sebagai ibu kota baru (yang tidak hanya akan mendukung fungsinya sebagai pusat administrasi pemerintahan) jumlah penduduk kota tersebut dipastikan nantinya akan meningkat, di sekitar wilayah ibu kota akan tumbuh berbagai macam kegiatan ekonomi yang akan terus berkembang. Kesemuanya itu akan bermuara pada peningkatan kebutuhan sumber daya, termasuk energi.

Energi adalah mesin penggerak kegiatan; tanpa keberadaan energi kegiatan administrasi pemerintahan, jasa-jasa maupun transportasi dan industri secara luas di sekitar kota tidak mungkin dapat berlangsung. Sebuah Ibu Kota tidak akan dapat menjalankan fungsinya dengan baik bila ketersediaan dan sistem pemanfaatan energinya tidak handal dan berkelanjutan, termasuk di IKN baru di Kalimantan Timur nantinya. Energi akan menjadi salah satu tantangan utama bagi beroperasinya kegiatan-kegiatan di IKN baru.

Kalimantan memiliki cadangan sumberdaya energi yang cukup besar, dari sumber fosil maupun terbarukan. Selama ini Kalimantan berfungsi sebagai penghasil energi (minyak bumi, gas bumi, batubara) maupun hasil-hasil hutan yang sebagian besarnya diekspor ke luar pulau, ke luar negeri, menjadikan Indonesia negara pengekspor energi kelas dunia dan Kalimantan penyumbang terbesarnya.

Bagaimana memenuhi kebutuhan energi di IKN tersebut nantinya? Bagaimana cara untuk mengkonsumsi energi di sana, yang sesuai dengan prinsip-prinsip pemanfaatan energi yang baik?

Makalah ini mengusulkan prinsip-prinsip yang perlu diperhatikan bagi upaya pemasokan dan konsumsi energi untuk IKN di Kalimantan Timur, dengan mempertimbangkan sistem energi di Kalimantan sekarang secara luas. Secara lintas makalah ini mengulas kondisi cadangan energi di Kalimantan, infrastruktur energi yang telah dibangun, serta mengusulkan pola penyediaan energi dan pemanfaatan energi untuk IKN baru di Kalimantan Timur.

\section{Cadangan yang mencukupi}

Kalimantan memiliki cadangan bahan bakar fosil yang kaya termasuk minyak bumi, gas bumi, dan batubara; serta cadangan bahan bakar fosil non-konvensional seperti coal bed methane dan oil-gas shale yang belum dieksploitasi. Cadangan tersebut tersebar tidak merata, dengan Kalimantan Timur memiliki jumlah terbanyak. (Lihat Gambar 1 dan Gambar 2). Namun, Kalimantan Barat hampir tidak memiliki potensi energi fosil seperti yang dimiliki propinsi lainnya. ${ }^{3}$

\footnotetext{
${ }^{2}$ Diumumkan Presiden Jokowi 16 Agustus 2019. Gagasan menjadikan pulau Kalimantan -yang terletak strategis di tengah-tengah Negara Kepulauan Indonesia-- sebagai Ibu Kota NKRI sebenarnya telah dikemukakan cukup lama, oleh Presiden pertama NKRI Ir. Soekarno.

${ }^{3}$ Sebaliknya Kalimantan Barat memiliki cadangan uranium (bahan bakar nuklir) yang sampai sekarang belum dieksploitasi, serta sumberdaya mineral non-energi, terutama bauksit dalam jumlah sangat besar, yang hampir tidak dimiliki oleh propinsi-propinsi Kalimantan lainnya.
} 
Minyak bumi mulai dieksploitasi lebih seabad lalu di Kalimantan bagian Timur (di pulau Bunyu dan Tarakan, kini wilayah Kalimantan Utara). Gas bumi dalam skala besar dihasilkan di Kalimantan Timur (wilayah Kutai Kartanegara) pada awal 1970-an, dikembangkan menjadi LNG (liquefied natural gas) di Bontang-Kaltim, kemudian dikirimkan ke negara-negara industri Asia Timur (Jepang, Taiwan, Korsel). Ekspor LNG tersebut (ditambah dengan Arun di Aceh) pernah menjadikan Indonesia negara pengekspor LNG terbesar dunia (Nugroho, 2011, 2012).

Indonesia masih tercatat sebagai salah satu pengekspor batubara terbesar di dunia, dan Kalimantan Timur serta Kalimantan Selatan adalah penghasil batubara yang produksinya sebagian besar diekspor tersebut. Batubara dari Kalimantan juga dikirimkan ke berbagai wilayah di Indonesia, terutama pulau Jawa dimana batubara dijadikan bahan bakar bagi PLTU (Pembangkit Listrik Tenaga Uap).

Tidak hanya bahan bakar fosil yang Kalimantan memiliki cadangannya cukup besar, namun juga sumber-sumber energi terbarukan. Indonesia adalah produsen $\mathrm{CPO}$ (crude palm oil) terbesar di dunia, dan Kalimantan adalah lokasi terbesar selain Sumatera dimana perkebunan sawit Indonesia yang juga terluas di dunia itu berada. ${ }^{4}$

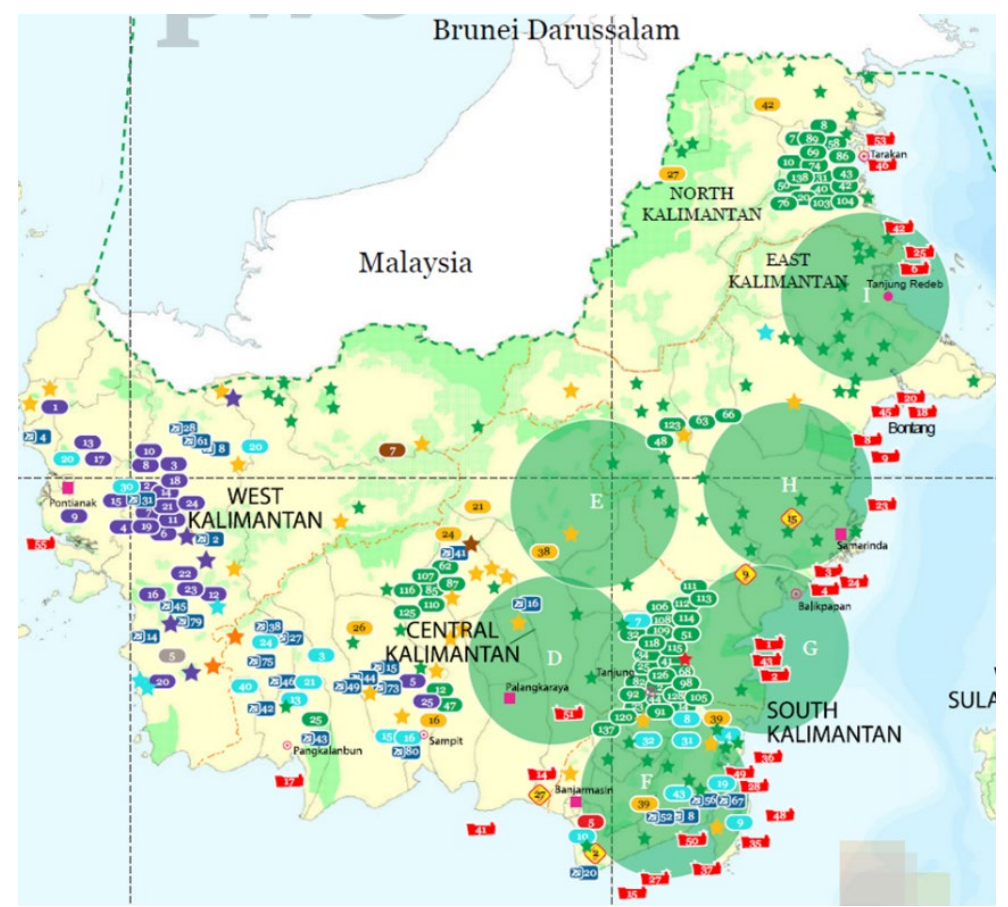

Gambar 1. Konsesi batubara dan mineral Kalimantan

Sumber: Price Waterhouse Cooper

\footnotetext{
${ }^{4}$ Biomass dari kelapa sawit, termasuk POME (palm oil mill efluent), dapat dimanfaatkan sebagai sumber energi, baik sebagai minyak (oil) maupun gas yang dapat dibakar langsung ataupun dijadikan bahan bakar bagi pembangkitan tenaga listrik. Indonesia sekarang adalah produsen biodiesel terbesar di dunia yang dibuat dari CPO (crude palm oil), berasal dari perkebunan-perkebunan kelapa sawit di Kalimantan dan Sumatra.
} 


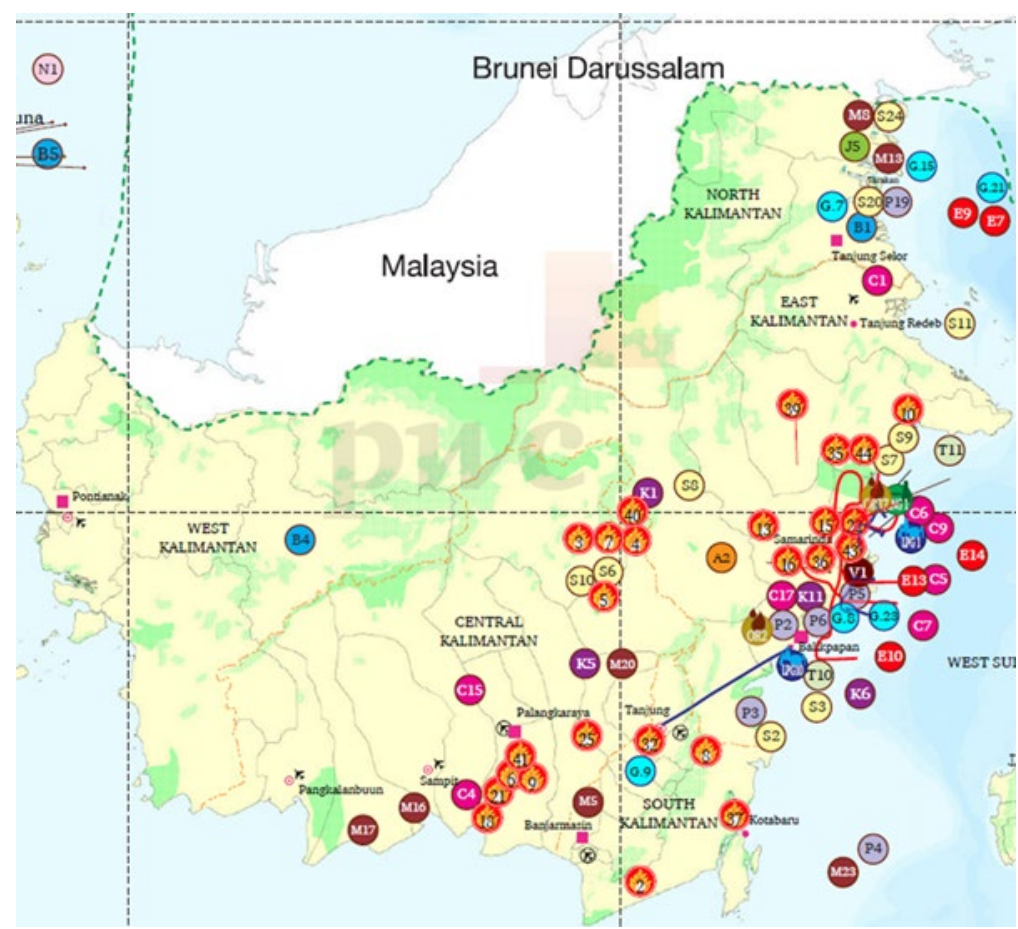

Gambar 2. Konsesi minyak dan gas bumi di Kalimantan

Sumber: Price Waterhouse Cooper

Berbagai infrastruktur energi telah dikembangkan di Kalimantan untuk memanfaatkan ketersediaan cadangan energinya yang besar.

Kilang minyak Balikpapan (kapasitas pengolahan 260.000 barel per hari) adalah kilang minyak kedua terbesar di Indonesia, setelah kilang Cilacap di Jawa Tengah. Awalnya kilang minyak ini didesain untuk memanfaatkan minyak mentah yang diproduksi lapanganlapangan minyak di Kalimantan bagian timur, namun dalam perkembangannya -seiring dengan permintaan produk-produk minyak yang terus meningkat dan menurunnya produksi minyak mentah lokal Kalimantan-masukan kilang diperkaya dengan menampung minyak mentah dari berbagai lapangan lain, termasuk impor. ${ }^{5}$

Kapasitas LNG Plant Badak di Bontang-Kaltim masih termasuk besar di dunia (8 trains, kapasitas pengolahan 22.5 MTPA - million ton per annum). Di pulau Kalimantan terletak pula LNG Plant berkapasitas besar yang lain, yaitu LNG Plant Bintulu (Sarawak Malaysia), dan LNG Plant Lumut (Brunei Darussalam), menjadikan Kalimantan sebagai pulau pengekspor LNG besar di dunia dengan 3 negara pengekspor di pulau yang sama. ${ }^{6}$ Ekspor LNG dari ketiga negara di pulau yang sama ini ke negara-negara industri Asia Timur telah menjadikan Asia Timur kawasan perdagangan LNG terbesar di dunia (Nugroho, 2018).

\footnotetext{
${ }^{5}$ Belakangan di kilang minyak Balikpapan dilakukan proyek peluasan kapasitas kilang (bagian dari proyek RDMP - Refinery Development Master Plan) sebelum upaya pemerintah menambah kilang-kilang minyak baru, termasuk di pulau Kalimantan, akan diwujudkan.

${ }^{6}$ Kapasitas Bintulu LNG Plant 1-3 adalah 18.8 MTPA, sedangkan Lumut LNG Plant adalah 7.2 MTPA. Sumber: US Energy Information Administration, 2019.
} 


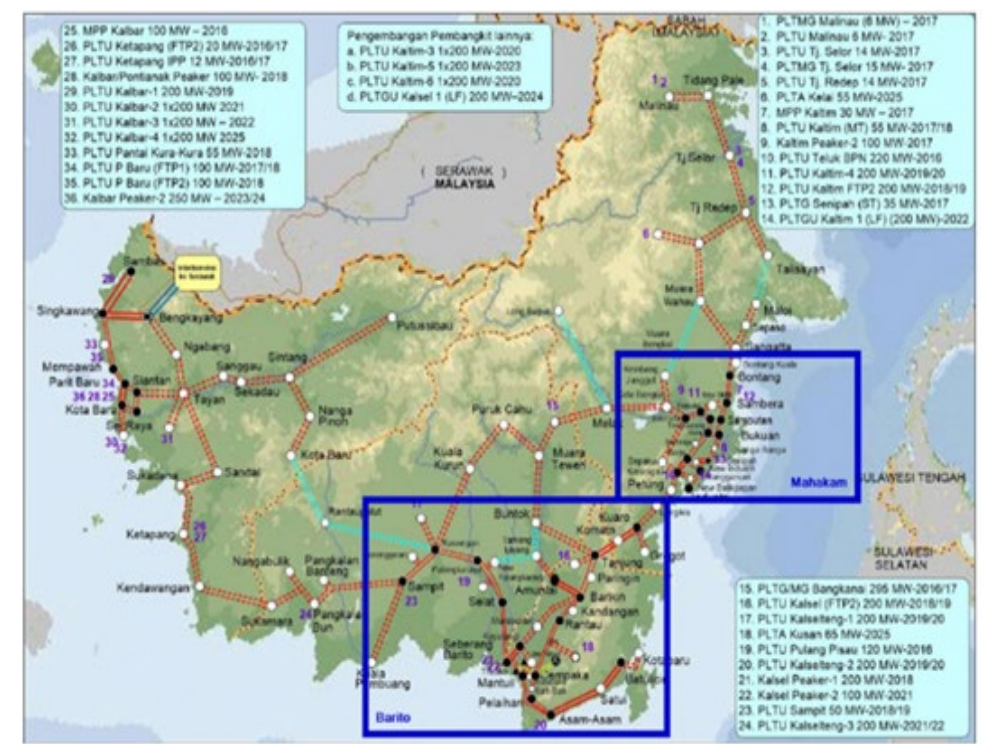

Gambar 3. Infrastruktur kelistrikan Kalimantan Sumber: RUPTL 2019-2028

Sungai-sungai di Kalimantan Timur dan Selatan (Mahakam, Barito, dsb.) menjadi prasarana awal bagi batubara Kalimantan utuk dikirimkan ke tujuan-tujuannya lintas samudra (Cina, India, Jepang, dll.). Armada batubara yang berasal dari wilayah Kalimantan bagian timur ini adalah terbesar/terbanyak dalam jenisnya di dunia, sekitar 1/3 dari global coal seaborne. ${ }^{7}$ Di banyak tempat di Kalimantan telah dibangun pelabuhan batubara (lihat Gambar 1) bukan saja untuk mengirimkan batubara ke tujuan-tujuan ekspor di dunia, namun juga ke wilayah-wilayah lain di Indonesia terutama pulau Jawa yang membutuhkan banyak batubara untuk digunakan sebagai bahan bakar PLTU. Peningkatan kapasitas pembangkitan listrik yang dilakukan di banyak tempat di Indonesia, misalnya melalui proyek 35.000 MW dalam Rencana Pembangunan Jangka Menengah Nasional (RPJMN) 2015-2019, mengandalkan batubara untuk bahan bakar.

Sebagian besar dari pembangkit tenaga listrik di Kalimantan berbahan bakar dari sumber-sumber fosil, terutama batubara. Terdapat pula pembangkit listrik dari energi terbarukan, khususnya PLTA dengan kapasitas terbatas (Gambar 3). Kelima propinsi di Kalimantan belum terkoneksi dengan jaringan transmisi listrik. Kalimantan Timur adalah wilayah yang memiliki infrastruktur terbaik se-Kalimantan. Kalimantan Barat (masih) terpisah dari sistem transmisi kelistrikan pulau Kalimantan (bagian Indonesia), bahkan sekarang mengimpor listrik dari Sarawak (Malaysia). ${ }^{8}$

Tak hanya untuk infrastruktur minyak bumi, gas bumi, dan kelistrikan, Kalimantan dengan 5 propinsinya (Kalbar, Kalteng, Kalsel, Kaltim, Kaltara) sesungguhnya merupakan pulau yang belum ter-interkoneksi dengan baik, bahkan untuk infrastruktur yang lebih dasar seperti jalan darat. Infrastruktur energi yang telah dibangun di Kalimantan pun lebih banyak dimanfaatkan untuk menunjang ekspor, atau pemakaian di luar pulau Kalimantan.

\footnotetext{
${ }^{7}$ Data misalnya dari Argusmedia.com atau APBI-ICMA.

${ }^{8}$ Dokumen RUPTL (Rencana Umum Penyediaan Tenaga Listrik) PT PLN memberikan gambaran cukup rinci mengenai kondisi kelistrikan di Indonesia, termasuk Kalimantan.
} 


\section{Prinsip dasar penyediaan dan konsumsi energi}

Kebutuhan energi di Kalimantan akan segera meningkat setelah ditetapkannya status wilayah Kalimantan sebagai IKN baru NKRI. Kebutuhan energi mulai muncul ketika proyek pembangunan ibu kota baru dilakukan, meningkat seiring dengan tumbuhnya kegiatankegiatan kota yang diikuti perkembangan industri, dsb., termasuk di wilayah-wilayah sekitarnya. Kebutuhan listrik dari kota pemerintahan yang baru didirikan akan datang dari aktivitas perkantoran serta pemukiman pegawai pemerintahan, termasuk jasa-jasa yang berkembang (pendidikan, rumah sakit, mall, dsb.). Sebelum industri manufaktur akan bertambah dan mendekat ke Kalimantan bukan saja karena fungsinya sebagai ibu kota tapi juga karena posisi geografisnya yang strategis (dekat dengan negara-negara industri Asia Timur dibandingkan dengan dari Jawa ke negara-negara tersebut), maka kebutuhan industri untuk mengoperasikan infrastruktur ibu kota kota baru (pelabuhan, lapangan terbang, dsb.) juga akan meningkat cepat. ${ }^{9}$

Memperhatikan besarnya cadangan berbagai macam sumber energi di Kalimantan, baik yang tak terbarukan (fosil) maupun terbarukan, segi "energy availability" tidaklah akan menjadi persoalan besar bagi ibukota baru di Kalimantan tersebut. Namun demikian penyediaan energi di Kalimantan nantinya (yang permintaannya banyak dibangkitkan karena keberadaan IKN) perlulah mempertimbangkan banyak hal lainnya. Mutu (keandalan) dari sistem penyediaan energi di Kalimantan juga dituntut untuk semakin baik (untuk memenuhi standar sebuah IKN), yang berarti pula peningkatan kebutuhan energi. Konektivitas energi antarpropinsi, bahkan intrapropinsi di Kalimantan juga dituntut untuk semakin diperluas/diperbaiki, bahkan mungkin akan dikembangkan setara atau lebih baik daripada yang telah dibangun selama ini untuk melayani pasar di luar Kalimantan.

Kalimantan menjadi ibukota NKRI, hal ini akan menimbulkan permintaan besar terhadap (berbagai macam) energi. Tidak saja bahwa tantangan untuk memenuhi kebutuhan energi di Kalimantan itu harus dapat dijawab, namun perlu mengindahkan pula syarat-syarat bagi pembangunan dan pemanfaatan energi yang semakin berkembang, misalnya sesuai arahan kebijakan mengenai Pembangunan Rendah Karbon (Low Carbon Development), Sustainable Development Goals, Kalimantan yang semakin hijau, dan sebagainya. Persyaratan tersebut perlu diterapkan tidak saja dalam "sisi penyediaan energi" (khususnya pembangkitan dan transformasi energi), namun juga untuk pemanfaatannya oleh sektorsektor lain (transportasi, industri, rumah tangga, perkantoran, dsb.).

Untuk mendukung peran Kalimantan sebagai IKN Kesatuan Republik Indonesia, untuk sisi energi, kami mengusulkan sejumlah strategi energi atau kebijakan dasar sebagai berikut:

1. Tidak hanya fokus pada penyediaan energi untuk IKN, tapi pemindahan IKN ke Kalimantan Timur juga dijadikan momentum untuk mengembangkan sistem penyediaan energi pulau Kalimantan secara luas.

2. Mengandalkan pemenuhan kebutuhan energi dari sumber-sumber lokal Kalimantan.

Sedapat mungkin menggunakan sumber-sumber energi yang berada di Kalimantan, baik bahan bakar fosil maupun non-fosil. Menghindarkan impor dari pulau-pulau lain, termasuk menekan impor crude oil dari sumber-sumber internasional.

3. Mengutamakan sumber-sumber energi Kalimantan untuk Kalimantan terlebih dahulu.

\footnotetext{
${ }^{9}$ Perlu riset cukup detil terlebih dahulu untuk memperkirakan "demand for energy" bagi IKN baru dan sekitarnya. Permintaan energi di IKN nantinya berpotensi akan meningkat $>100$ kali dibandingkan permintaan energi di wilayah tersebut sebelum dijadikan IKN.
} 
Sumber-sumber energi yang berada di Kalimantan, termasuk yang bersifat transportable/exportable diutamakan untuk memenuhi kebutuhan Kalimantan terlebih dahulu, baru kemudian kelebihannya dapat dikirimkan untuk memenuhi kebutuhan pulau-pulau di Indonesia lainnya, dan internasional. Misalnya hal ini untuk batubara.

4. Mengutamakan penggunaan energi bersih dan terbarukan.

Prioritaskan pemanfaatan energi yang berasal dari sumber-sumber energi terbarukan, seperti air (PLTA), PV (photo-voltaic, tenaga surya), dan biomass. Utamakan pemanfaatan energi yang "lebih bersih" di antara sumber-sumber energi fosil yang terdapat di Kalimantan, misalnya memprioritaskan gas bumi dibanding batubara.

5. Mengembangkan/memperkokoh interkoneksi infratruktur energi se-Kalimantan. Interkoneksi infrastruktur energi se-Kalimantan (bagian Indonesia) dikembangkan dengan menghubungkan propinsi-propinsi se Kalimantan, baik untuk kelistrikan maupun infrastruktur energi lainnya. Pengembangan infrastruktur energi diutamakan awalnya untuk wilayah IKN.

6. Menggunakan energi secara efisien.

Sistem transportasi, industri, maupun kegiatan-kegiatan ekonomi lainnya yang akan dikembangkan di Kalimantan harus menerapkan prinsip-prinsip pemanfaatan energi secara efisien.

\section{Proyek energi strategis}

Selain menerapkan kebijakan dasar seperti disebutkan di atas, kami usulkan beberapa proyek strategis pembangunan energi yang harus dilakukan, yaitu: ${ }^{10}$

1. Pembangunan jaringan transmisi gas bumi dari lokasi ketersediaan gas bumi (atau LNG) di Kalimantan Timur ke kota di Kalimantan yang menjadi IKN Kesatuan Republik Indonesia. Pembangunan ini disertai dengan pembangunan jaringan distribusi gas bumi di IKN, diikuti dengan pembangunan jaringan distribusi gas bumi di kota-kota yang dilintasi jaringan transmisi gas bumi. Tahap selanjutnya adalah pengembangan jaringan transmisi gas bumi Trans Kalimantan diikuti dengan wilayah-wilayah distribusinya.

2. Penguatan jaringan transmisi interkoneksi kelistrikan se-Kalimantan. Jaringan transmisi Kalseltengtim yang kini telah terinterkoneksi perlu segera disambungkan dengan jaringan Kalimantan Barat, sehingga terbentuk jaringan interkoneksi kelistrikan se-Kalimantan. Semakin kuatnya interkoneksi sistem Kalimantan sekaligus akan menghindarkan impor listrik (yang selama ini dilakukan oleh "Sistem Katulistiwa" Kalimantan Barat dari Sarawak) digantikan dengan arus listrik yang dihasilkan oleh berbagai pembangkit listrik lainnya se-Kaalimantan. Demikian pula, jaringan jalan raya maupun perkapalan Trans Kalimantan yang telah terbentuk dapat dimanfaatkan sebagai infrastruktur untuk penyaluran energi, khususnya yang berbentuk bulk atau cair seperti batubara dan minyak bumi.

3. Pembangunan PLTA skala besar memanfaatkan potensi sungai-sungai besar di Kalimantan. Pembangunan PLTA dapat dimulai dengan pemanfaatan tenaga air sungai Kayan di Kalimantan Utara, dilengkapi dengan pembangunan jaringan transmisi jarak jauh yang menghubungkannya dengan sistem transmisi terinterkoneksi Kalimantan. Pembangunan serupa dilakukan untuk memanfaatkan potensi sungai-sungai besar seperti Kapuas di Kalimantan Barat, Mahakam di Kaltim maupun Barito di Kalsel. Tidak saja bahwa pembangunan tersebut akan 10 Telah mempertimbangkan sejumlah dokumen perencanaan seperti RPJMN 2015-2019 (dan draft 2020-2024),
RUPTL (Rencana Umum Penyediaan Tenaga Listrik) 2018-2027 dan beberapa tahun sebelumnya. 
mendukung kelistrikan di IKN namun juga untuk dapat digunakan bagi pembangunan kawasan-kawasan industri yang akan berkembang di Kalimantan nantinya.

4. Pembangunan installasi dan penggunaan energi bersih. Kalimantan perlu membangun banyak pembangkit listrik dan bahan bakar lainnya dari sumbersumber energi "bersih" di Kalimantan, terutama sumber energi terbarukan. Hutanhutan yang luas dapat menghasilkan biomass dalam skala yang masif untuk didayagunakan sebagai sumber energi bersih. Tenaga matahari yang tercurah melimpah di Kalimantan yang terletak di sekitar jalur katulistiwa (equator) merupakan sumber energi yang dapat dikembangkan optimal di Kalimantan. Di antara bahan bakar fosil, terdapat bahan bakar yang "lebih bersih" dibandingkan lainnya. Gas bumi adalah sumber energi "bersih" yang Kalimantan banyak memilikinya dan industrinya telah cukup lama dikembangkan (meskipun awalnya adalah untuk melayani ekspor). Gas bumi adalah sumber energi yang terbersih dibandingkan sumber energi fosil lainnya (batubara dan minyak bumi). Gas bumi di Kalimantan perlu dikembangkan intensif, baik untuk dibakar langsung (di rumah-rumah tangga, industri, dsb.) maupun sebagai bahan bakar di pembangkitan listrik. Batubara (sebagai yang dianggap "kotor") tetap perlu dimanfaatkan (mengingat keberadaan cadangannya yang sangat besar) namun dengan memanfaatkan teknologi "super critical" yang tinggi efisiensinya dan pembakarannya lebih bersih dibandingkan dengan teknologi yang kini masih banyak dipakai di Indonesia.

5. Pembangunan sistem transportasi hemat energi dan ramah lingkungan. Ibu kota baru harus dilengkapi dengan sistem transportasi yang ramah lingkungan serta hemat energi, misalnya mengandalkan transportasi umum-kota berbasis kereta ringan, pemakaian sepeda secara masif oleh penduduk kota, penggunaan mobil listrik dibandingkan mobil menggunakan BBM. Kota juga dirancang "compact" meminimumkan pergerakan yang tidak perlu yang dilakukan oleh penduduk kota. Kantor-kantor pemerintahan dan swasta di IKN dirancang sebagai "energy efficcient building" dengan memaksimumkan keberadaan sinar matahari dan lingkungan yang hijau. Pembangunan sistem transportasi serta perkantoran yang hemat energi dan ramah lingkungan selanjutnya dikembangkan pula di kota-kota lainnya di Kalimantan. Prinsip serupa diterapkan untuk pembangunan kawasan-kawasan industri, dan seterusnya.

\section{Rekomendasi}

Memperhatikan latar belakang Kalimantan sebagai pulau yang memiliki kekayaan sumber-sumber energi, dan dipilihnya kota di Kalimantan menjadi IKN Kesatuan Republik Indonesia, untuk itu kami rekomendasikan hal-hal yang berkaitan dengan pengembangan energi di Kalimantan sebagai berikut:

A. Pokok-pokok kebijakan atau strategi energi, meliputi:

1) Mengandalkan pemenuhan kebutuhan energi dari sumber-sumber lokal

2) Kalimantan. Mengutamakan sumber-sumber energi Kalimantan untuk Kalimantan terlebih dahulu.

3) Mengutamakan penggunaan energi bersih dan terbarukan.

4) Mengembangkan/memperkokoh interkoneksi infratruktur energi seKalimantan.

5) Menggunakan energi secara efisien.

B. Proyek strategis pembangunan energi yang harus dilakukan:

1) Pembangunan jaringan transmisi gas bumi dari lokasi ketersediaan gas bumi (atau LNG) di Kalimantan Timur ke IKN. 


\section{Hanan Nugroho}

2) Penguatan jaringan transmisi interkoneksi kelistrikan se-Kalimantan.

3) Pembangunan PLTA skala besar memanfaatkan potensi sungai-sungai besar di Kalimantan.

4) Pembangunan installasi dan penggunaan energi bersih.

5) Pembangunan sistem transportasi hemat energi dan ramah lingkungan.

\section{Referensi}

Nugroho, H. (2011). A mosaic of Indonesian energy policy. Bogor: IPB Press.

Nugroho, H. (2012). Energi dalam perencanaan pembangunan. Bogor: IPB Press.

Nugroho, H. (2018). Thoughts on Indonesian energy issues \& policies. Bogor: IPB Press.

Perusahaan Listrik Negara. (2018). Rencana Umum Penyediaan Tenaga Listrik 2018-2027. Jakarta: PT PLN (Persero).

Price Waterhouse Cooper. (2018). Peta-peta energi dan sumberdaya mineral Indonesia (diambil dari beberapa penerbitan). Jakarta: PWC-Indonesia (https://www.pwc.com/id/en.html)

Republik Indonesia. (2015). Rencana Pembangunan Jangka Menengah Nasional 2015-2019. Jakarta: Badan Perencanaan Pembangunan Nasional. 